Article

\title{
A System Dynamics Approach to Modeling Groundwater Dynamics: Case Study of the Choshui River Basin
}

\author{
Yun-Hsun Huang, Yan-Jiang Lai and Jung-Hua Wu *
}

check for

updates

Citation: Huang, Y.-H.; Lai, Y.-J.; $\mathrm{Wu}, \mathrm{J}$.-H. A System Dynamics Approach to Modeling Groundwater Dynamics: Case Study of the Choshui River Basin. Sustainability 2022, 14, 1371. https://doi.org/ $10.3390 /$ su14031371

Academic Editor: Fernando António Leal Pacheco

Received: 4 January 2022

Accepted: 22 January 2022

Published: 25 January 2022

Publisher's Note: MDPI stays neutral with regard to jurisdictional claims in published maps and institutional affiliations.

Copyright: (C) 2022 by the authors. Licensee MDPI, Basel, Switzerland. This article is an open access article distributed under the terms and conditions of the Creative Commons Attribution (CC BY) license (https:// creativecommons.org/licenses/by/ $4.0 /)$.
Department of Resources Engineering, National Cheng Kung University, Tainan 701, Taiwan; z10808014@email.ncku.edu.tw (Y.-H.H.); xfjioyhnplus@gmail.com (Y.-J.L.)

* Correspondence: hwaa@mail.ncku.edu.tw

\begin{abstract}
Land subsidence resulting from the overexploitation of groundwater is an important issue in the Choshui River Basin, Taiwan. In the current study, we employed system dynamics simulation in modeling the supply of surface and groundwater, as well as the demand for water by industry, water deficits, and mechanisms underlying land subsidence. The proposed model was then used to estimate the magnitude of land subsidence and evaluate various management strategies. Our simulation results revealed that the vigorous enforcement of well sealing would have a modest effect on land subsidence; however, it would also have notable adverse effects on the agricultural community. We determined that reducing the demand for irrigation water (e.g., by switching to less water-intensive crops) would reduce land subsidence, while preserving profitability in those areas. In the future, this policy could be complemented by promoting the adoption of advanced irrigation technology and automatic systems to further slow the excessive exploitation of groundwater, with a corresponding effect on land subsidence.
\end{abstract}

Keywords: land subsidence; groundwater overexploitation; sustainability; system dynamics; management strategies

\section{Introduction}

Fresh water is a precious resource, due largely to the fact that humans have direct access to only $2.53 \%$ of all the earth's water [1]. In 2015, the United Nations (UN) proposed the Sustainable Development Goals (SDGs), including 'Clean Water and Sanitation' (Goal 6), aimed at ensuring that all humans have access to water and sanitation. Access to fresh water also promotes the goals of 'No Poverty' (Goal 1), 'Zero Hunger' (Goal 2), 'Sustainable Cities and Communities' (Goal 11), 'Climate Action' (Goal 13), and 'Life on Land' (Goal 15).

Growing populations and economic development are increasing the demand for fresh water, and advances in hydrogeology, prospecting, pumping technology, and rural electrification have increased groundwater extraction [2]. Overexploitation of groundwater causes water tables to decline, such that aquifer systems become compressed. This leads to land subsidence, which can have a permanent effect on water storage capacity and underground infrastructure [3].

Land subsidence is an important concern in Taiwan, particularly along the southwestern coasts. In 2020, the land sank more than three centimeters in some areas, mostly in the Choshui River basin between Yunlin and Changhua counties. Severe land subsidence can have a profound influence on above-ground structures, such as threatening the operation of high-speed rails and highways. It can also lead to the salinization of coastal aquifers via saltwater intrusion, undermining soil quality and increasing the frequency of flooding [4].

Land subsidence in Taiwan is caused mainly by groundwater overexploitation, due largely to uneven temporal and spatial distributions of rainfall. The Choshui River basin has no large-scale water storage facilities, which means that local industries must compete to extract groundwater for development. Governmental interventions are required to slow 
down the extraction of groundwater. The issue of land subsidence involves water supply, water demand, water deficits, and policy instruments under the effects of time delays and nonlinear causality. Therefore, effective management strategies for land subsidence depend on systematic analysis.

In accordance with grounded theory, we collated extensive literature on the driving forces of land subsidence from foreign and domestic sources. We then identified the key factors via grouping and clustering on which to develop a system dynamics (SD) model. The SD approach is well-suited to dynamic systems characterized by interdependence, mutual interaction, information feedback, and nonlinear causality. It has also proven effective in studying problems that arise in balancing and reinforcing loops. For highly complex groundwater systems, the SD approach can be used to capture interdependencies and feedback between various subsystems. This also allows for the presentation of relationships between factors using causal loop diagrams. In the current study, we employed Vensim PLE to construct an SD model by which to characterize the dynamic groundwater balance and simulate accumulated land subsidence. The proposed system was applied to the Choshui River basin with the intention of deriving insights by which to formulate effective policy aimed at mediating land subsidence.

The remainder of this paper is structured as follows. Section 2 presents a review of the literature pertaining to SD in the context of water resources. Section 3 describes the methodology and data used in this paper. Section 4 presents simulation results under various scenarios. The final two sections respectively provide a discussion of policy implications and conclusions.

\section{Literature Review}

SD has been used to explore economic growth [5], public policy [6], agricultural conservation [7], urban development [8], business development [9], financial systems [10], demographics [11], and environmental systems [12]. SD has proven highly effective at the quantitative simulation of the dynamic consequences of policies. In the current study, we explore the supply of, demand for, and management of water resources; therefore, this literature review focuses on the application of SD to water resource management.

Simonovic modelled global water resources using the SD approach [13]. The World Water Model was based on the last version of World3, in which water quantity and quality are presented in the context of population, agriculture, economy, nonrenewable resources, and persistent pollution. The total water stock in the model included precipitation, ocean resources, nonrenewable groundwater resources, and water recycling. The resulting simulations revealed a strong relationship between water resources and industrial growth, and identified pollution as the most important issue pertaining to global water levels.

Zhang and Mitsch used the SD model to investigate the hydrologic processes of four different flow-through-created freshwater wetlands in Ohio, USA [14]. Their model of a three-hectare riparian wetland developed using STELLA 7.0 featured dynamic interface level controls, surface water inflow and outflow, precipitation, evapotranspiration, and groundwater seepage. They determined that the hydroperiod of the wetland provided more than sufficient flooding to ensure that it met the criteria for jurisdiction as a wetland. Water budget predictions provide useful information pertaining to hydroperiod and hydrologic dynamics prior to the construction of stormwater wetlands.

Chen et al. combined a driving-force-state-response (DSR) framework and the SD model by which to establish the dynamic strategy planning procedure [15]. They also considered the integrated management of land, water, and air resources in river basin systems. Their combination of modified land-use management methods with DSR dynamic strategy planning procedure demonstrated the efficacy of these techniques for urban and regional planning.

Khan et al. demonstrated the application of SD in two case studies with dynamicallylinked processes, including seepage from a river, evaporation from a shallow water table, groundwater storage, and lateral flow from upland to lowland areas [16]. Their model 
is applicable to the simulation of responses to irrigation management scenarios aimed at developing strategies by which to improve water use efficiency, prevent salinization, and reduce the cost of groundwater abstraction in lowland areas.

Wei et al. developed a complex SD model of the interactions between water resources, environmental flow, and socioeconomic indicators in the Weihe River basin of China [17]. Their model comprised nine subsystems, including population, industry, agriculture, water demand, wastewater and its treatment technology and policy, water resources, water balance, ecology, and environment water demand, as well as environmental flow requirements. Their results obtained under four alternative socioeconomic growth patterns demonstrated the efficacy of their approach to modeling dynamic behavior in order to identify optimal growth patterns.

The Singapore Water SD model developed by Xi and Poh revealed that investing in only groundwater storage or surface water catchments is insufficient to achieve water self-sufficiency [18]. They also determined that if Singapore invests in desalination or wastewater reclamation only after the water supply shows signs of stress, water shortages could ensue for up to five years, thereby illustrating the need to build water infrastructures well in advance.

Balali and Viaggi adopted the SD approach to modeling groundwater dynamics under various economic policies and climate change scenarios [19]. They used STELLA software to create a dynamic hydroeconomic model by which to elucidate the interactions among the economic behavior of farmers, groundwater aquifer dynamics, climatic conditions, and economic policy on the vulnerability of groundwater under dry, normal, and wet conditions. They demonstrated that the implementation of economic policies related to irrigation water and energy pricing can significantly affect groundwater exploitation and its volume balance. They also demonstrated that climate change can affect groundwater recharge, and that precipitation is positively correlated with aquifer recharge rates.

Alifujiang et al. adopted the SD approach to develop a dynamic water balance model of the Issyk-Kul Lake basin for the period from 1980 to 2012 [20]. Results based on sensitivity analysis revealed that changes in lake water levels could be attributed primarily to water withdrawal from lake tributaries, changes in land use, and increases in population water demand, as well as evaporation and precipitation.

Ghasemi et al. employed the SD approach to develop a management strategy to deal with water resources in metropolitan Tehran, Iran [21]. The results showed that despite the diminishing availability of water resources, optimizing the use of existing resources could reduce water deficit within 30 years.

Mokhtar and Aram developed an SD model to investigate the hydrologic and socioeconomic aspects of groundwater balance in an Iranian agricultural plain [22]. The results of the business-as-usual policy scenario demonstrated the ineffectiveness of current governmental policies at maintaining a regional balance in groundwater. They also ran their model under different mitigation policies, including methods aimed at improving irrigation efficiency and groundwater recharge under agricultural expansion. Their results indicated that re-establishing regional balance in groundwater distribution within the next 30 years could be achieved as long as irrigation efficiency is improved while maintaining the current level of agricultural production.

Pluchinotta et al. developed an SD model to elucidate the means by which actions influence the decision making of stakeholders in an interaction space [23]. Their model has been used to evaluate the impact on water management policies and identify critical feedback in the dynamic evolution of the system. Their research was not intended to optimize water allocation, price decisions, or crop planning. Rather, their objective was to illustrate for decision makers the potential consequences of their decisions. The results of their work could be used as a starting point for future research dealing with the complexity of water management and policy design.

Bai et al. employed SD modeling to determine the hydrologic and economic implications of irrigation efficiency (IE) policy in a coupled sociohydrologic system under three 
climatic scenarios [24]. Simulations were conducted on the lower Rio Grande region (LRG) of New Mexico, USA, for the period from 1969 to 2099. These simulations included water, land, capital, and population modules. Results revealed current policies are capable of increasing abundance by $4.7 \sim 74.5 \%$ and return flow by $-3.0 \sim 9.9 \%$. However, these positive results would come at the cost of decreased hydrologic connectivity ( -31.5 to $-25.1 \%)$ and negative economic growth ( -32.7 to $-5.7 \%)$.

Conventional modeling schemes cannot be used to characterize dynamic feedback relationships between the physical aspects of water balance and population growth, the development of agriculture and industry, technological developments, or the use of other resources. A review of the literature revealed that $\mathrm{SD}$ is an effective tool in the field of water resource management; however, it has not been widely used to model groundwater dynamics in regions of severe land subsidence.

Over the past decade, numerous studies have been conducted on groundwater and land subsidence in Taiwan; however, there has been considerable variation in their focus and the dimensions they address. Some researchers have sought to predict the probability of land subsidence, whereas others have conducted numerical simulations of groundwater flow. There has been research on land subsidence monitoring, the analysis of groundwater extraction, and the development of algorithms (e.g., genetic algorithms and neural networks) to estimate soil compression parameters. Relatively little research has addressed the issue of water resources management or the formulation of policy instruments to deal with land subsidence.

Based on the theory of collaborative governance, Lo explored environmental issues, the collaboration process, and design of systems aimed at mitigating land subsidence in the Yunlin and Changhua areas [25]. They identified a number of factors influencing collaborative governance mechanisms, including the transfer of resources from the central government to local governments, coordination between ministries and governments, consistency in objectives of various sectors, and the soundness of supervision and accountability mechanisms. They emphasized the importance of addressing the concerns of all stakeholders in land subsidence prevention, creating channels to facilitate citizen participation, and enhancing mechanisms for external supervision.

Liao and Chen proposed a subsidy policy aimed at mitigating land subsidence and flood problems associated with the overuse of groundwater by farmers in Da-Cheng Township, Taiwan [26]. They simulated the required total subsidy expense and the monetary value of avoided flood damages from alleviating the land subsidence, and determined that the benefit-cost ratios from the proposed subsidy regulations were all higher than that from the Flood Control Program currently adopted by the government. Under the specific regulations suggested in this study, the ratio can be as high as 1.15 , which means that using a limited budget efficiently requires addressing the underlying issues as early as possible.

Lo focused exclusively on the influence of interministry collaboration on land subsidence prevention, entirely avoiding the issue of policy implementation [25]. Liao and Chen examined the effects of policy implementation from the perspective of subsidy policies [26]; however, they did not consider the effects of other mechanisms on land subsidence. This is the first study to employ SD as a decision-support tool in the analysis of land subsidence areas in the Choshui river basin, including nonlinear causality and information feedbacks among interlinked variables, as well as the processes governing groundwater drawdown. This paper contributes to the literature on SD for water resource management by incorporating the concepts of grounded theory to facilitate the identification of factors that are crucial to the SD model, rather than selecting factors arbitrarily.

\section{Materials and Methods}

\subsection{Selection of Key Factors-The Concept of Grounded Theory}

Grounded theory was developed by two sociologists, Glaser and Strauss, in 1967 [27]. This systematic methodology begins with the collection of qualitative data, from which ideas/concepts emerge. The concepts are then tagged using codes that provide a succinct 
summary. The ongoing collection and review of these codes enables the grouping and categorization of concepts to form hypotheses. This emergent aspect of grounded theory differs from the traditional scientific model of research, in which the researcher selects an existing theoretical framework from which hypotheses are derived, and data collection is intended only for hypothesis testing.

The issue of land subsidence is complex and multifaceted. In accordance with grounded theory, we conducted an extensive review of the literature, analyzed primary research results, and selected relevant factors.

Key factor selection was implemented in three steps:

1. We began with a comprehensive review of the literature covering supply, demand, and policy. Supply included the development of water conservancy facilities, the excavation and sealing of water wells, and the construction of groundwater recharge facilities. Demand included water for agriculture, water for aquaculture, and water for industrial parks. Policy included water price adjustments and rewards for using recycled water.

2. We then consolidated common factors based on segments and keywords repeatedly mentioned in the literature.

3. Finally, we coded the factors and segments with the aim of identifying relationships among Level 1 codes in order to form higher-level concepts in accordance with the primary categories, such as supply and demand.

Table 1 presents an example constructed using the above steps. Our primary objective was to identify the key factors influencing land subsidence from which to develop the SD model. In the current study, we employed the concept of grounded theory to overcome the subjective selection of components used in existing SD studies.

\subsection{System Dynamics Model}

Complex issues cannot be resolved from an event-oriented perspective or through the use of simple linear thinking. SD provides a number of tools by which to model and analyze dynamic interactions in complex systems [28]. The most important feature of SD is its applicability in elucidating the endogenous structure of systems, including interactions among the various elements within the context of decision making. SD bases the relationship between structure and behavior on the concept of information feedback and control. Accordingly, time delays, amplifications, and structural relationships among system elements often play a more important role than individual components in determining system-level phenomena.

The identification of causal loops can facilitate the establishment of SD models. Land subsidence is caused by groundwater exploitation, which can be modelled as an imbalance between supply and demand. Thus, the proposed SD model is based on the interactions among water supply, water demand, and land subsidence (see Figure 1).

As shown in Figure 2, we expanded the aspects of supply and demand. The downwardpointing arrow at the top of the figure indicates the source of recharge; i.e., rainfall. The two-way arrow between water supply and land subsidence at the bottom of the figure indicates an interactive relationship. Industry-level demand is obtained by multiplying the area of land in use by the water demand per unit area in that industry. In other words, the demand for water in each industry is given by the area of land in use multiplied by irrigation, aquaculture, and industrial water demand per unit area. Total water demand is obtained by summing industrial-level demands. The difference between the supply and demand is referred to as the deficit, which in turn influences the supply and demand. This represents a causal loop. Supply is broken down into surface water and groundwater. The difference between groundwater use and recharge serves as the basis for land subsidence calculations. 
Table 1. Example of key factor selection.

\begin{tabular}{|c|c|c|c|}
\hline Main Category & Level 2 & Level 1 & Concepts Drawn from Literature \\
\hline \multirow{7}{*}{ Supply } & \multirow{3}{*}{ Use of surface water } & $\begin{array}{l}\text { Inadequate interception of surface } \\
\text { runoff }\end{array}$ & $\begin{array}{l}\text { Insufficient planning of water for home } \\
\text { use and irrigation, resulting in } \\
\text { groundwater exploitation by the public } \\
\text { and private sectors }\end{array}$ \\
\hline & & \multirow{2}{*}{$\begin{array}{l}\text { Development of water } \\
\text { conservancy facilities }\end{array}$} & $\begin{array}{l}\text { Government investment in water supply } \\
\text { facilities for the allocation of surface } \\
\text { water resources }\end{array}$ \\
\hline & & & $\begin{array}{l}\text { Development of water resource facilities } \\
\text { aimed at increasing the water supply, } \\
\text { such as the Hushan Reservoir and } \\
\text { Niaozueitan Artificial Lake }\end{array}$ \\
\hline & \multirow{4}{*}{ Use of groundwater } & \multirow{3}{*}{ Water well management and sealing } & $\begin{array}{l}\text { Implementation of water well } \\
\text { management and industrial planning to } \\
\text { mediate water usage }\end{array}$ \\
\hline & & & $\begin{array}{l}\text { Ceasing all subsidies involving } \\
\text { consumables and power consumption } \\
\text { leading to groundwater exploitation }\end{array}$ \\
\hline & & & $\begin{array}{l}\text { Management of existing illegal wells, } \\
\text { prevention of new illegal wells, and an } \\
\text { annual reduction in the number of } \\
\text { publicly operated water wells }\end{array}$ \\
\hline & & Groundwater recharge & $\begin{array}{l}\text { Installation of groundwater recharge } \\
\text { facilities in Yunlin and Changhua }\end{array}$ \\
\hline \multirow{8}{*}{ Demand } & \multirow{6}{*}{ Water use by industry } & \multirow[t]{2}{*}{$\begin{array}{l}\text { Changes in use of water for } \\
\text { agricultural irrigation }\end{array}$} & $\begin{array}{l}\text { Provision of rewards to promote the } \\
\text { conversion of farms irrigated with } \\
\text { groundwater to dry farming or } \\
\text { afforestation, or leaving such } \\
\text { farms fallow }\end{array}$ \\
\hline & & & $\begin{array}{c}\text { Converting } 6000 \text { hectares of farmland to } \\
\text { dry farming and } 2000 \text { hectares of flatland } \\
\text { to afforestation }\end{array}$ \\
\hline & & \multirow{2}{*}{$\begin{array}{l}\text { Changes in use of water } \\
\text { for aquaculture }\end{array}$} & $\begin{array}{l}\text { Government allocation of coastal areas } \\
\text { with poor soil in Yunlin and Changhua to } \\
\text { freshwater aquaculture }\end{array}$ \\
\hline & & & $\begin{array}{l}\text { Gradual replacement of freshwater } \\
\text { aquaculture with seawater aquaculture }\end{array}$ \\
\hline & & \multirow[b]{2}{*}{ Industrial water use } & $\begin{array}{l}\text { Majority of water supply for industry } \\
\text { from wells }\end{array}$ \\
\hline & & & $\begin{array}{l}\text { More pronounced impact of deep water } \\
\text { wells than shallow wells on } \\
\text { land subsidence }\end{array}$ \\
\hline & \multirow[t]{2}{*}{ Other water uses } & $\begin{array}{l}\text { Water price adjustments in response } \\
\text { to changes in demand }\end{array}$ & $\begin{array}{l}\text { Establishing a reasonable water price } \\
\text { structure aimed at controlling } \\
\text { consumption to prevent waste: the } \\
\text { adoption of tiered pricing and removal of } \\
\text { basic fees, while accounting for the costs } \\
\text { involved in developing water resources }\end{array}$ \\
\hline & & Rewards for using recycled water & $\begin{array}{l}\text { Encouraging major water users to } \\
\text { employ water-saving equipment and } \\
\text { recycle water }\end{array}$ \\
\hline
\end{tabular}




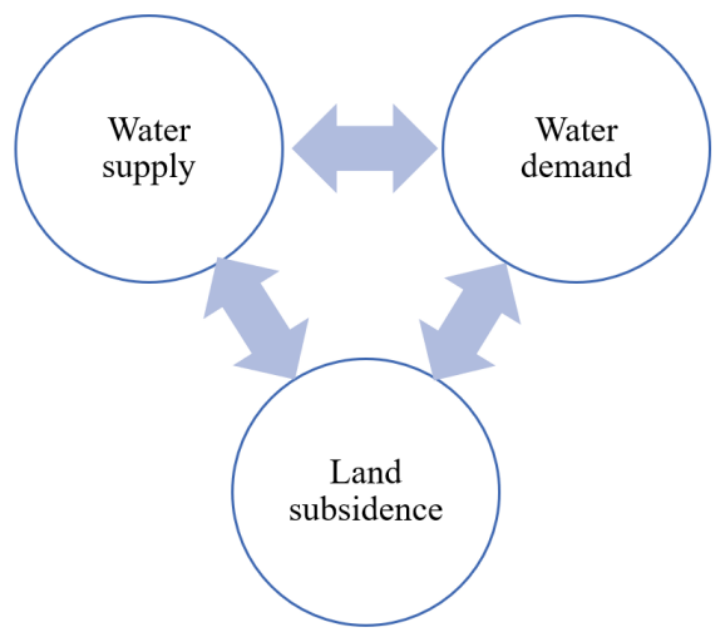

Figure 1. Relationships among water supply, water demand, and land subsidence.

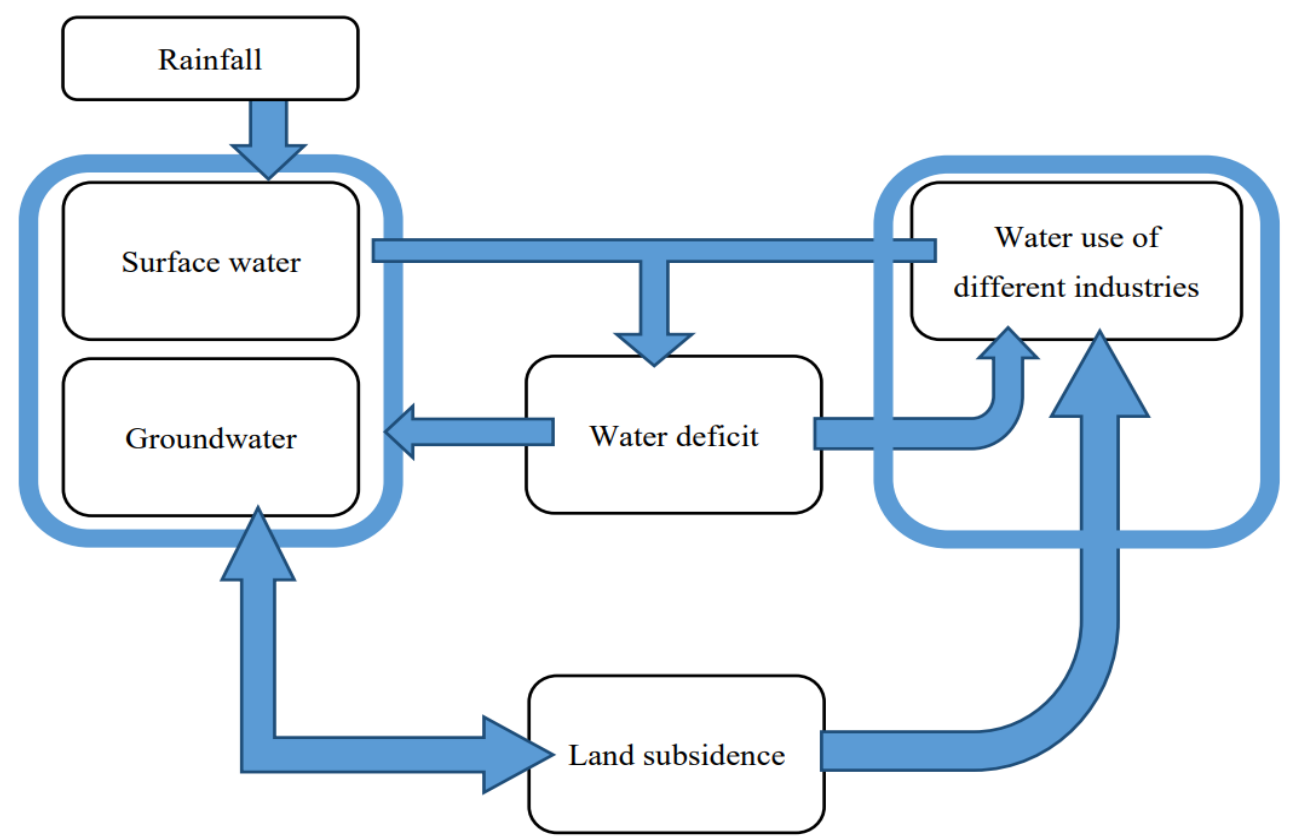

Figure 2. Relationships among surface water, groundwater, water use by various industries, water deficits, and land subsidence.

We created stock-flow diagrams for the Choshui River basin in accordance with the principles of SD, a series of casual loops, and mathematical equations (see Appendix A). The proposed model uses the concepts of water balance and rainfall-runoff transformation to estimate the availability of water for agriculture and industry. The model respectively generates water demand data for agriculture and industry based on land use expansion, changes in water demand, and the effect of time delays.

As shown in Figure 3, the relationships and stock-flow diagrams were formulated using the SD software package "Ventana Simulation Environment Personal Learning Edition" (Vensim PLE) [29]. The plus sign indicates an increase in the variable at the head of the nearby arrow, whereas the minus sign indicates a decrease in that variable. Furthermore, this figure illustrates the relations between key components and feedback mechanisms of the system, including several balancing (B) and reinforcing (R) loops. 


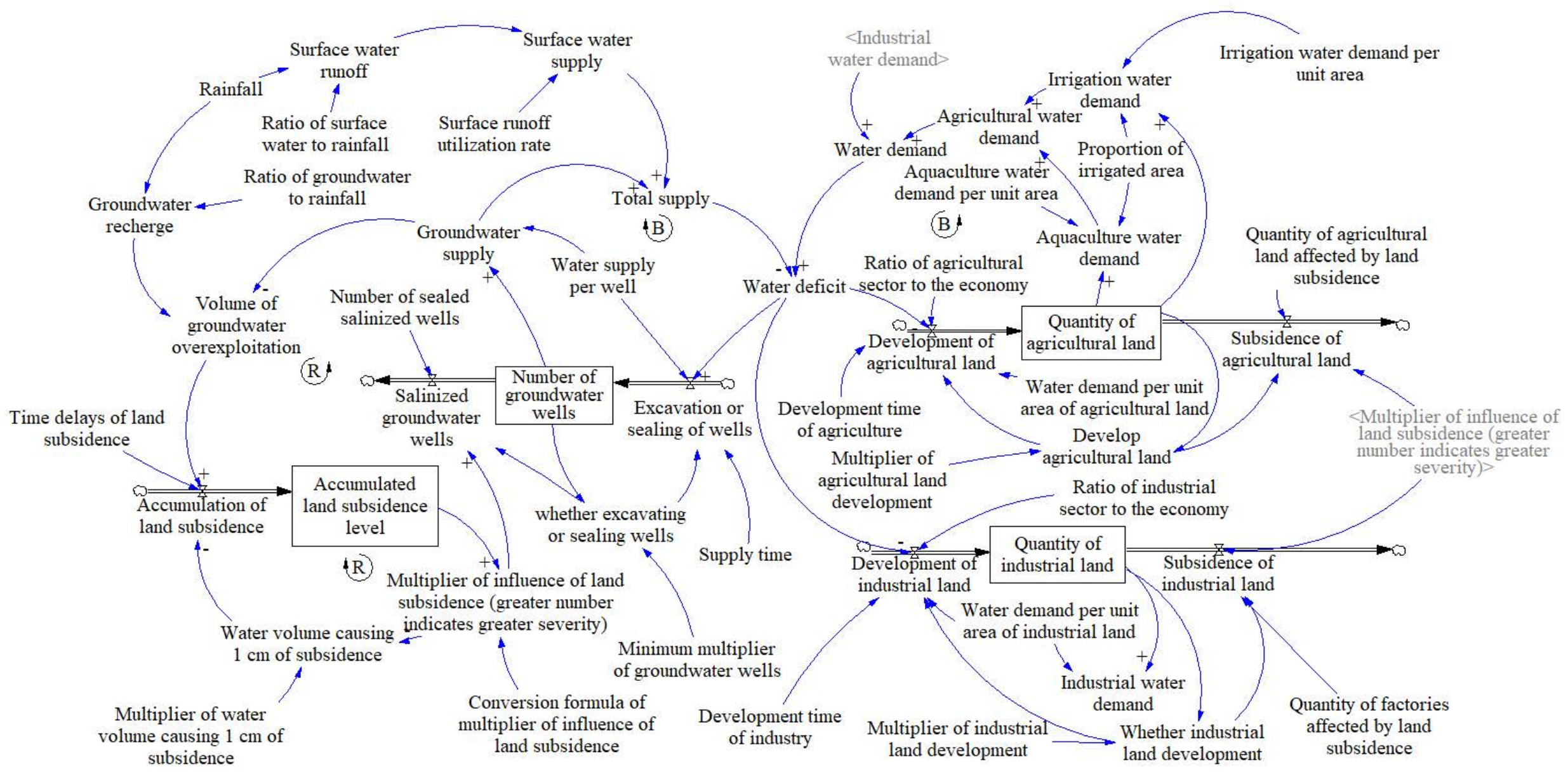

Figure 3. Stock-flow diagram of dynamic hydrological system in Choshui River basin. 
In Figure 3, water deficit is located at the center, and the demand for water resources is on the right. Land area is a dichotomous variable; i.e., it comprises both agricultural and industrial land. Water demand is correlated mainly with land area as follows: land area times water demand per unit area for crops, aquaculture, or industry, respectively. The current model assumes that further land development is possible as long as there are sufficient water resources. We also assumed that more wells will be excavated when water resources fail to satisfy demand. The proposed model also takes the effect of time delays into account.

The upper left portion of Figure 3 indicates the availability of water resources, where rainfall (at the top) is divided into surface water (on the right) and groundwater recharge (below). The level variable of groundwater supply is represented by the number of groundwater wells. Multiplying the average volume of water extracted from each well (a fixed value) by the number of wells gives us the total water extracted from wells (i.e., groundwater supply). Adding the total available surface water to the total well-supplied water gives us the total water supply.

Land subsidence mechanisms are presented in the lower left corner of Figure 3. The downward arrow indicates the conversion of rainfall to groundwater (i.e., groundwater recharge). Subtracting groundwater demand from groundwater recharge gives us the volume of groundwater overexploitation. Multiplying by the groundwater overexploitation value by the volume of water required to cause one centimeter of land subsidence gives us the accumulated land subsidence. We also sought to account for the effects of land compaction under the effects of subsidence, which can have a negative effect on the rate of subsidence.

The overall methodology flowchart is illustrated in Figure 4. This flowchart provides a step-by-step guide outlining the integration of grounded theory and system dynamics modeling.

\subsection{Data Sources}

\subsubsection{Study Area}

The Choshui River basin is located along the midwestern coast of Taiwan, including the counties of Changhua and Yunlin. The Choshui River runs from east to west through the study area (Figure 5), which covers approximately $1800 \mathrm{~km}^{2}$ across the two counties. The alluvial plain is surrounded by geographic boundaries, including the Taiwan Strait (to the west), the Central Mountain Ridge (to the east), the Wu River (to the north), and the Beigang River (to the south) [30]. Measurements of groundwater level in the aquifers revealed two prominent flow directions: northwest from a mountainous area in the east (Changhua) and southwest (Yunlin) [31].

Given the insufficient surface water supply in the area, agricultural communities and industries extract groundwater to supplement their demands for irrigation, aquaculture, and industrial use. Hence, groundwater overdraft causes serious land subsidence, especially during droughts. In this study, we collected data related to the Choshui River basin (Changhua and Yunlin) for use as parameters in the SD model.

\subsubsection{Data Required for SD Model}

We collected open-access statistical data and reports from government sources (e.g., websites), including the surface water-rainfall ratio; groundwater-rainfall ratio; surface runoff utilization rate; area of land under agricultural and industrial development; water demand for irrigation, aquaculture, or industrial use per unit area; proportion of land area under agricultural or industrial development; and proportion of water used for irrigation, aquaculture, or industrial use. This data are listed in Table 2.

We also estimated some required data, including the average volume of water excavated from each well, the number of water wells, the number of wells sealed due to land subsidence, the effect of time delays, and the volume of water required to cause one centimeter of land subsidence. These data are listed in Table 3. The rationality of these estimates was verified by experts and specialists. 
The simulation was run for the period from 2020 to 2080 (60 years), in which 2020 was used as the base year and the modeling time-step was 1 year.

Simulation of groundwater dynamics in the Choshui River Basin

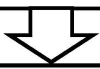

SD Model Preprocessing

Grounded Theory:

Identifying the key factors influencing land subsidence to overcome the subjective selection of components used in the SD model

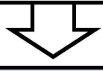

SD Model Establishment

Identification of causal loops

Determination of variables, including state variables, auxiliary variables, constants, and their relationships

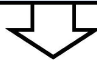

\section{SD Model Validation}

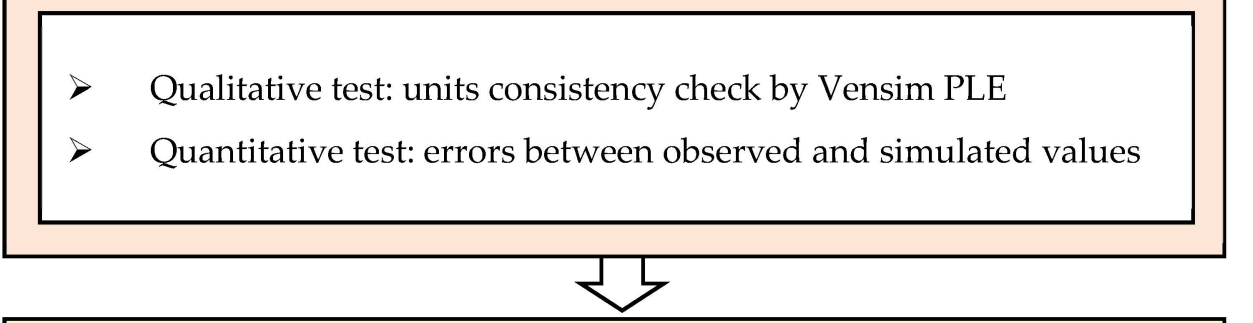

Scenario Selection and Simulation

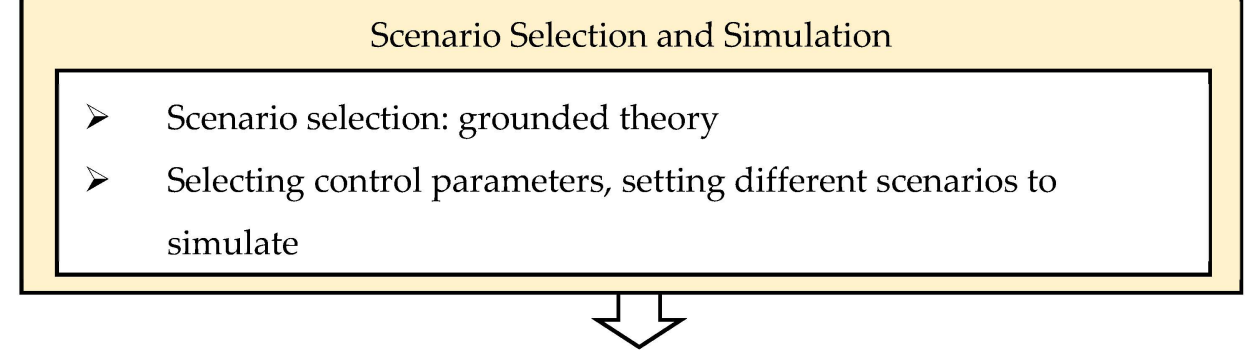

Simulation results analysis

Figure 4. Methodology flowchart of grounded theory and system dynamics model. 

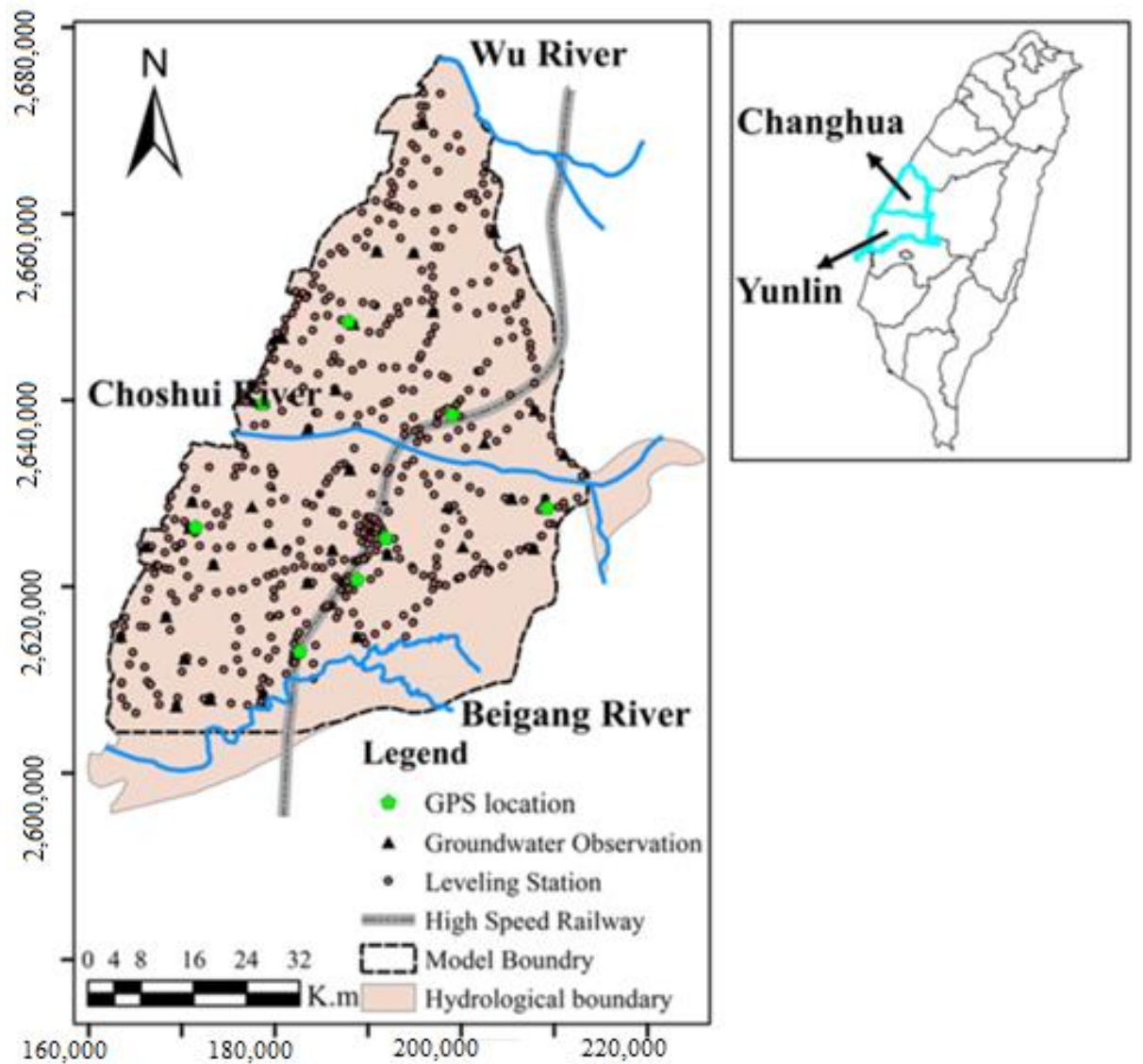

Figure 5. Map of Choshui River basin. Data source: Chu et al. [31].

Table 2. Data from open-access sources.

\begin{tabular}{|c|c|c|}
\hline Name & Quantity & Data Source \\
\hline Ratio of surface water to rainfall & 0.71 (no unit) & $\begin{array}{c}\text { Water Resources Agency, Ministry of } \\
\text { Economic Affairs }\end{array}$ \\
\hline Ratio of groundwater to rainfall & 0.04 (no unit) & $\begin{array}{c}\text { Water Resources Agency, Ministry of } \\
\text { Economic Affairs }\end{array}$ \\
\hline Surface runoff utilization rate & 0.16 (no unit) & $\begin{array}{c}\text { Water Resources Agency, Ministry of } \\
\text { Economic Affairs }\end{array}$ \\
\hline Area of land under agricultural development & 106,566 hectare & $\begin{array}{c}\text { Water Resources Agency, Ministry of } \\
\text { Economic Affairs }\end{array}$ \\
\hline Area of land under industrial development & 4978 hectare & $\begin{array}{l}\text { Water Resources Agency, Ministry of } \\
\text { Economic Affairs }\end{array}$ \\
\hline Water demand for irrigation per unit area & 14.2 thousand cubic meters per hectare & $\begin{array}{l}\text { Water Resources Agency, Ministry of } \\
\text { Economic Affairs and our estimates }\end{array}$ \\
\hline Water demand for aquaculture per unit area & 32.3 thousand cubic meters per hectare & $\begin{array}{l}\text { Water Resources Agency, Ministry of } \\
\text { Economic Affairs and our estimates }\end{array}$ \\
\hline Water demand for industry per unit area & 56.6 thousand cubic meters per hectare & $\begin{array}{l}\text { Water Resources Agency, Ministry of } \\
\text { Economic Affairs and our estimates }\end{array}$ \\
\hline Proportion of area used for irrigation & 0.9 (no unit) & $\begin{array}{c}\text { Water Resources Agency, Ministry of } \\
\text { Economic Affairs }\end{array}$ \\
\hline Proportion of area used for aquaculture & 0.1 (no unit) & $\begin{array}{c}\text { Water Resources Agency, Ministry of } \\
\text { Economic Affairs }\end{array}$ \\
\hline Proportion of water used for agriculture & 0.97 (no unit) & $\begin{array}{c}\text { Water Resources Agency, Ministry of } \\
\text { Economic Affairs }\end{array}$ \\
\hline Proportion of water used for industry & 0.03 (no unit) & $\begin{array}{c}\text { Water Resources Agency, Ministry of } \\
\text { Economic Affairs }\end{array}$ \\
\hline
\end{tabular}


Table 3. Data based on our estimates and verified by experts and specialists.

\begin{tabular}{ccc}
\hline Name & Quantity & Data Source \\
\hline Rainfall & 6.1 billion cubic meters & Our estimates and verified by experts \\
\hline $\begin{array}{c}\text { Average volume of water excavated from } \\
\text { each well }\end{array}$ & 100 thousand cubic meters per well & Our estimates and verified by experts \\
\hline $\begin{array}{c}\text { Number of water wells } \\
\text { Number of wells sealed due to } \\
\text { land subsidence }\end{array}$ & 150,000 wells & Our estimates and verified by experts \\
\hline Time delays effect & 500 wells annually for each $1 \mathrm{~cm}$ \\
of subsidence & Our estimates and verified by experts \\
\hline $\begin{array}{c}\text { Water volume causing } 1 \mathrm{~cm} \text { of } \\
\text { land subsidence }\end{array}$ & $\begin{array}{c}19,011 \sim 263,157 \text { thousand cubic } \\
\text { meters per cm }\end{array}$ & Our estimates and verified by experts \\
\hline
\end{tabular}

\section{Results}

\subsection{Scenario Design}

Three scenarios were established in accordance with the tenets of grounded theory, based on an extensive review of the literature and various strategies aimed at reducing land subsidence.

- $\quad$ Scenario 1-Vigorous enforcement of well sealing

One of the main causes of land subsidence is an excess of wells. In many situations, governments are unable to curtail groundwater exploitation, due in part to the fact that a complete ban could have a severe negative impact on industrial activity and the livelihoods of farmers and fishermen. The Taiwan government has adopted an interim measure in which approximately 500 wells are sealed each year for each $1 \mathrm{~cm}$ of subsidence [33]. Scenario 1 assumes the adoption of stronger measures in which the number of wells sealed annually is increased from 500 to 1500 for each $1 \mathrm{~cm}$ of subsidence.

- $\quad$ Scenario 2-Promotion of surface water utilization

Rainfall can become surface water or groundwater recharge. Roughly $16 \%$ of surface runoff ends up replenishing the water supply; i.e., most surface water flows into the ocean. Scenario 2 assumes that more dams are built in order to increase the utilization of surface water from $16 \%$ to $25 \%$.

- $\quad$ Scenario 3-Reduced demand for irrigation water per unit area

In the current study, we estimated the total water demand by multiplying land area by the water demand per unit area. Scenario 3 focuses on reducing net consumptive use of water for irrigation (from 14.2 thousand cubic meters per hectare to 10 thousand cubic meters per hectare), which can be realized by cultivation of less water-intensive crops (e.g., sorghum), using advanced irrigation technology and automatic systems.

\subsection{Simulation Results}

- $\quad$ Scenario 1-Vigorous enforcement of well sealing

Figure 6 presents the results of Scenario 1. The red line indicates the results of sealing 500 wells per year for each $1 \mathrm{~cm}$ of subsidence. The blue line indicates the land subsidence resulting from the sealing of 1500 wells per year. Clearly, implementing more vigorous well-sealing measures would have a moderate effect on land subsidence. 


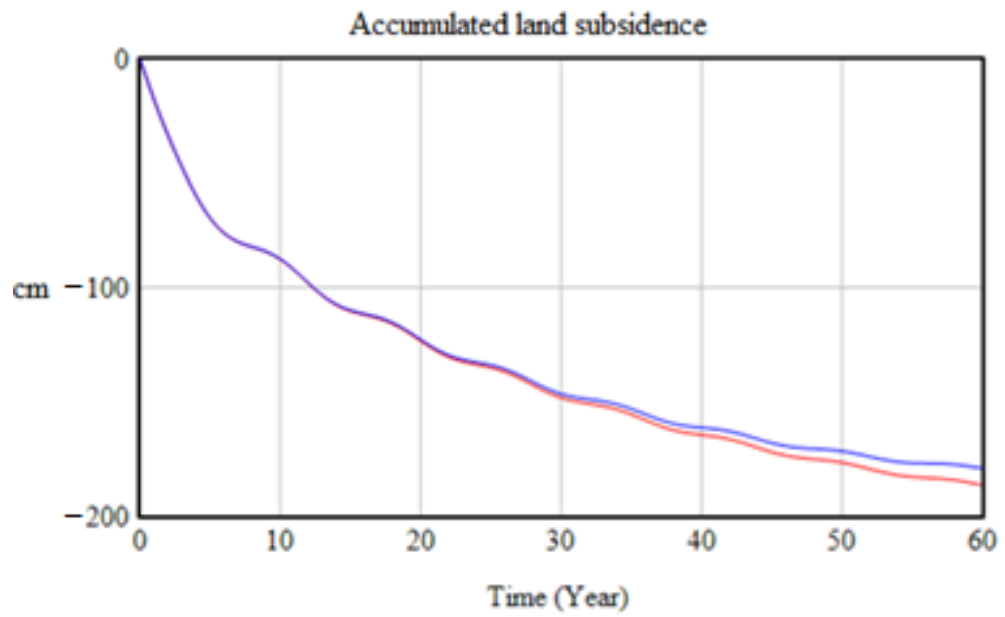

Figure 6. Simulated land subsidence under Scenario 1.

Figure 7 illustrates the land use results obtained under Scenario 1. From top to bottom, the three graphs present the total land use, industrial land use, and agricultural land use. The red lines indicate the results obtained when 500 wells are sealed each year for each $1 \mathrm{~cm}$ of subsidence (baseline scenario), and the blue lines indicate the results obtained when 1500 wells are sealed per year for each $1 \mathrm{~cm}$ of subsidence (Scenario 1). The relatively small discrepancy between the two lines indicates that well sealing had a negligible effect on land use.

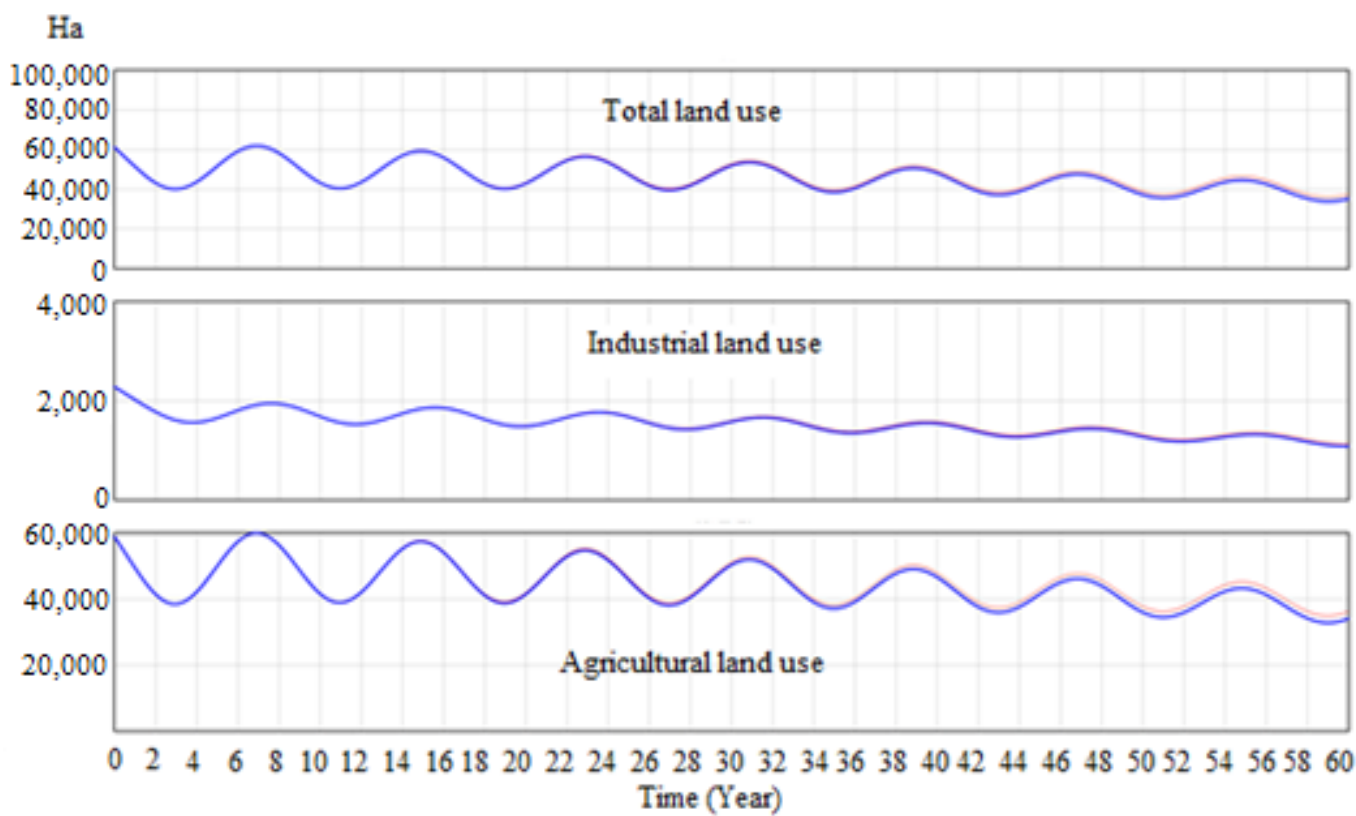

Figure 7. Simulated land use under Scenario 1.

- $\quad$ Scenario 2-Promotion of surface water utilization

Figure 8 displays the simulation results obtained under Scenario 2. The brown indicates the results obtained under the baseline scenario, in which only $16 \%$ of the surface runoff replenished the water supply, and the blue line presents the results obtained when water utilization was increased from $16 \%$ to $25 \%$ (Scenario 2). These results demonstrate that efforts aimed at increasing the surface water in place of groundwater could have a profound effect on reducing land subsidence. Scenario 2 outperformed the other scenarios in terms of the reduction in accumulated land subsidence. The strength of this scenario can probably be attributed to the large amount of rainwater in this region, such that even a 
modest increase in surface water utilization could have profound effects on the reduction in groundwater extraction.

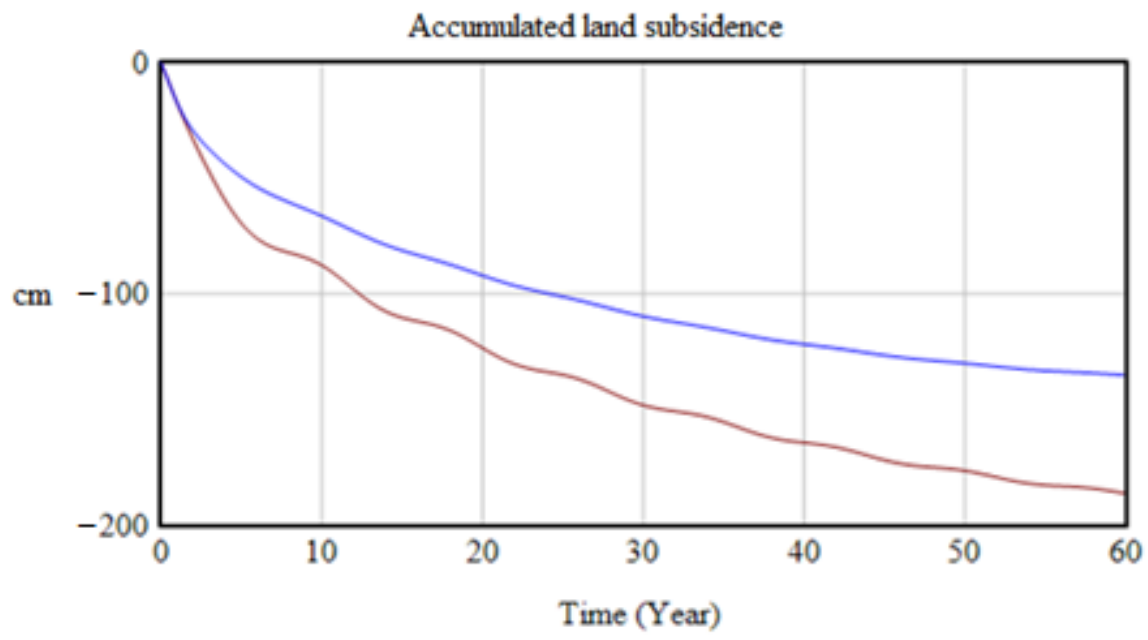

Figure 8. Simulated land subsidence under Scenario 2.

The brown lines in Figure 9 indicate the results obtained under the baseline scenario, and the blue lines indicate the results obtained under Scenario 2 (increasing surface water utilization). Based on historical usage data, it appears that $97 \%$ of the water supply is provided to agricultural land, while $3 \%$ is provided to industrial land. Thus, promoting surface water utilization would have a pronounced effect on agricultural land use. We also found that implementing Scenario 2 would have a positive effect on overall land use while reducing the fluctuation.

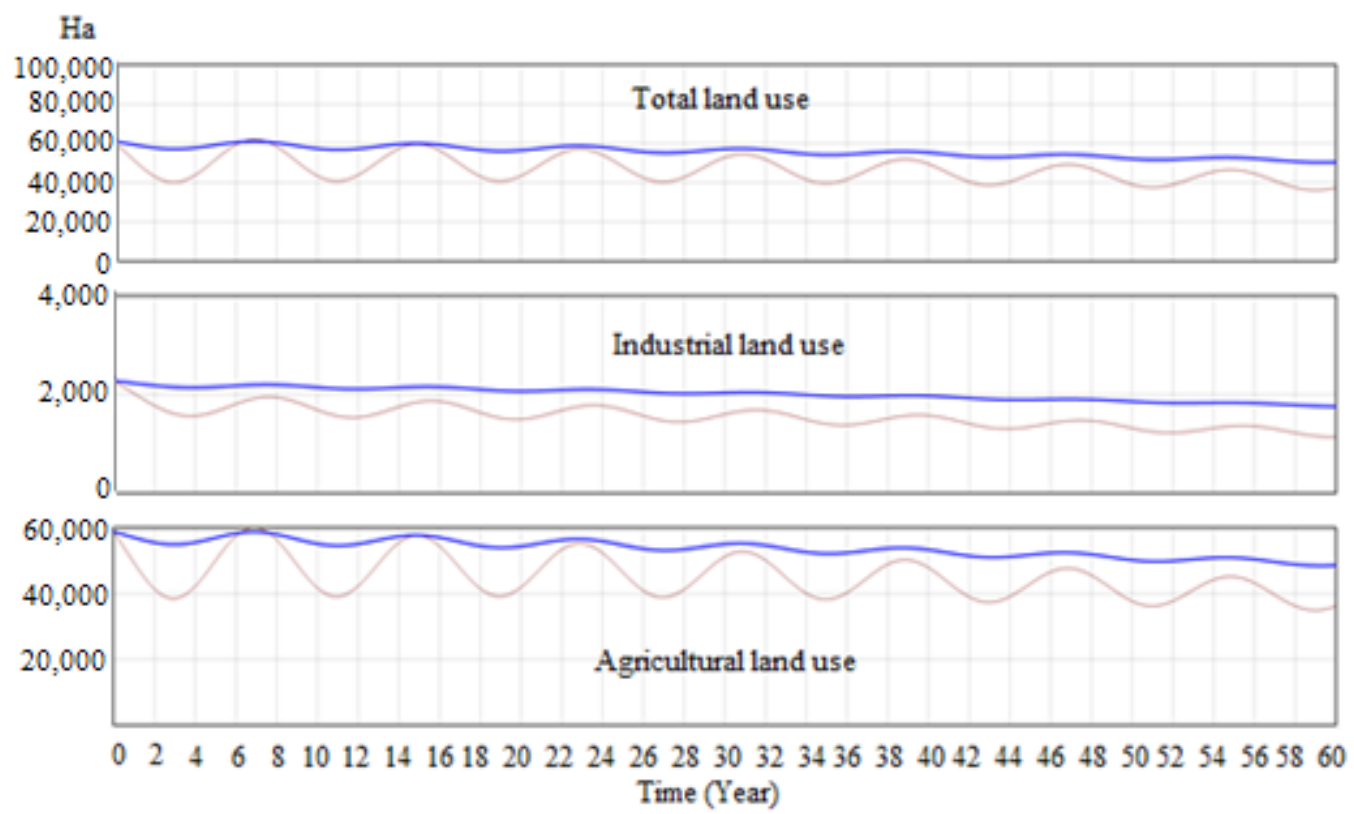

Figure 9. Simulated land use under Scenario 2.

- Scenario 3-Reduced demand for irrigation water per unit area

Figure 10 presents the simulation results obtained under Scenario 3 . The light blue line indicates the results obtained under the original demand for irrigation water (14.2 thousand cubic meters per hectare), and the dark blue line indicates the results obtained by reducing demand to 10 thousand cubic meters per hectare. Our results reveal that reducing the demand for irrigation water could indeed mediate land subsidence. Note however that demand in the current study included water for use in industry as well as agriculture, and 
agricultural water was further divided into irrigation and aquaculture. Thus, our results pertaining to irrigation water were not as significant as those obtained under Scenario 2.

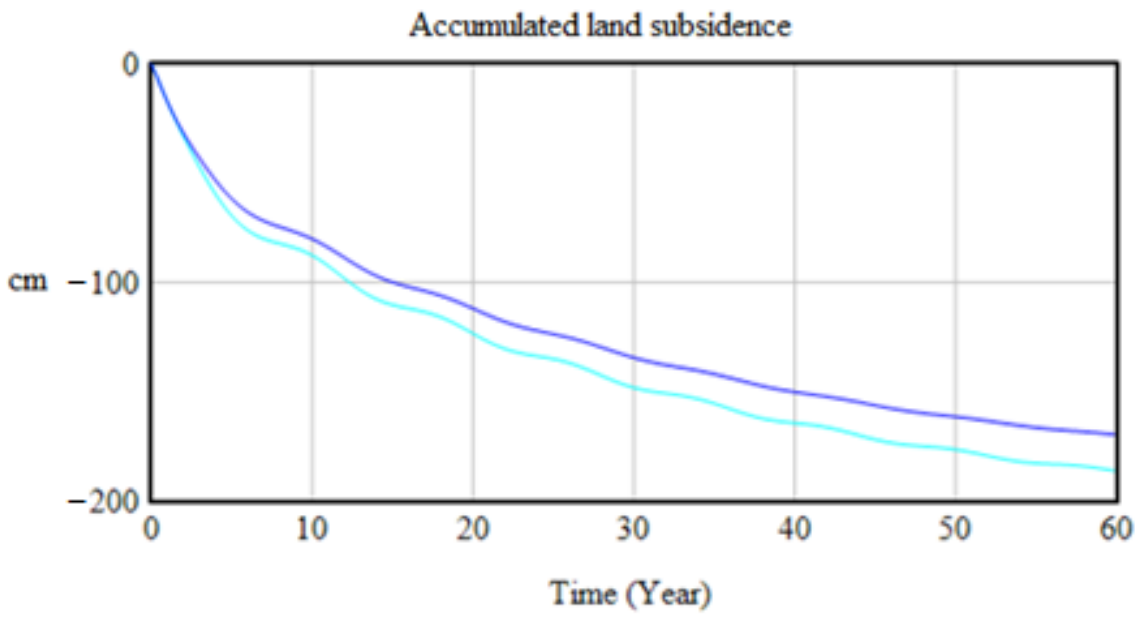

Figure 10. Simulated land subsidence under Scenario 3.

Figure 11 illustrates changes in land use obtained under Scenario 3. Reducing demand for irrigation water had a pronounced effect on agriculture, such that the growth in agricultural land use was greater than that before the adjustment, and in comparison, the increase in industrial land use was much smaller. Although the effect of irrigation water demand reduction can cause the system to underperform as compared with Scenario 2, Scenario 3 holds promise to mitigate the land subsidence while maintaining a steady condition for overall land use.

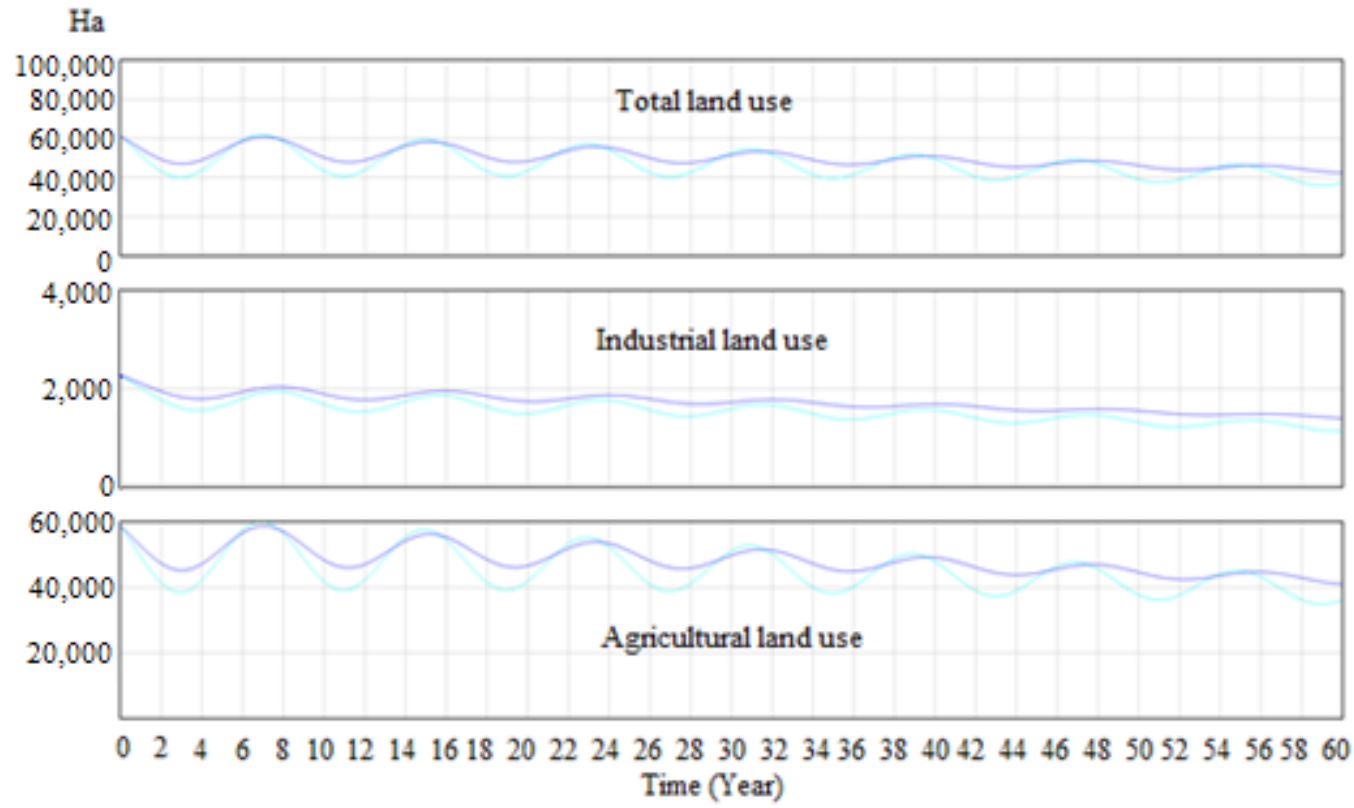

Figure 11. Simulated land use under Scenario 3.

\section{Discussion}

The three scenarios simulated in this study were meant to moderate land subsidence from the perspectives of supply and demand. Supply strategies included reducing the number of water wells (Scenario 1) and increasing the rate of surface water utilization (Scenario 2), both of which were shown to reduce the rate of groundwater exploitation. Scenario 3 focused on reducing net consumptive use of water for irrigation. Our results revealed that the enormous number of wells in the Choshui River basin (approximately $150,000)$ meant the impact of sealing 1500 wells per year for each $1 \mathrm{~cm}$ of subsidence would 
be negligible. Furthermore, restrictive policies (i.e., enforcement of well sealing) were not received well by agricultural producers due to adverse impacts on production, which in turn hurt the economic condition of the agrarian communities. Finally, monitoring the use of wells could prove to be an administrative nightmare.

Scenario 2 is meant to enhance the utilization of surface water by building more dams and improving water retention methods. This scenario would no doubt reduce land subsidence; however, implementing such methods would be time-consuming and costly. Furthermore, the construction of more dams has led to the extinction of many fish and other aquatic species; the disappearance of birds in floodplains; the extensive loss of forest, wetlands, and farmland; the erosion of coastal deltas; and other adverse environmental effects. Note, however, that this type of development can have tangible as well as intangible effects, and quantifying the impact would require additional data and sophisticated valuation methods from environmental economics. Our current SD model does not include a subsystem by which to quantify the economic losses associated with these environmental effects.

Scenario 3 is meant to mediate subsidence by reducing net consumptive water use for irrigation. In effect, it can also significantly decrease the land subsidence while maintaining profitability of agricultural production. For example, land subsidence in the Yunlin area of the Choshui River basin has shifted from coastal areas to areas along the high-speed rail. In 2020, the area suffering from significant land subsidence reached 103.8 square kilometers. The accumulated subsidence was $2.62 \mathrm{~m}$, and the average subsidence in 2020 was $5.5 \mathrm{~cm}$. In 2021, the government sought to mediate the overexploitation of groundwater by promoting the cultivation of less water-intensive crops (e.g., sorghum) and encouraging farmers to plant dry crops in areas within $1.5 \mathrm{~km}$ of the high-speed rail in Yunlin. Financial incentives for cultivation of less water-intensive crops include subsidies granted by the central government (NTD 45,000 per hectare (NTD stands for New Taiwan Dollar; on average (Year 2020), USD 1 is approximately equivalent to NTD 29.5)), subsidies granted by an environmental services program (NTD 5000 per hectare), and subsidies granted by the Yunlin County government (NTD 10,000 per hectare). Adding these subsidies to the profits from harvesting crops allows farmers to earn an average of NTD 114,000 per hectare simply by switching to sorghum. Sorghum crops are also time-efficient, such that the profits are comparable to those of rice. In the future, this policy could be complemented by promoting the adoption of advanced irrigation technology and automatic systems for hydrological data acquisition and transmission to further improve irrigation efficiency. In addition, appropriate land management policies should be implemented to ensure water savings are not used to increase crop production by expanding cultivated lands.

\section{Conclusions}

Land subsidence is a complex issue involving water supply, water demand, water deficits, and policy instruments. It is further complicated by time delays and various linear and nonlinear causalities. Devising management strategies for land subsidence requires systematic analysis. In the current study, we adopted the Choshui River basin in Central Taiwan as a case study in the construction of an SD model. The presented stock-flow diagrams and the simulation results provided insight into the groundwater management problem, where increasing groundwater withdrawal from a growing number of wells is pushing the system toward its limit in terms of availability of water resources. Consequently, significant groundwater table drawdown poses a serious threat to sustainability of industrial production in the region. This paper contributes to water-resource SD literature by explicitly capturing interdependencies and feedback between various subsystems in the simulation of management strategies for governing groundwater drawdown. Our results are summarized below.

Unlike existing SD studies in which system components are largely arbitrary, we employed grounded theory to facilitate the extraction of primary factors based on a review of the literature. We coded the factors as either supply or demand, due to the fact that 
groundwater exploitation can be attributed primarily to an imbalance between the two. The resulting SD model was implemented using Vensim PLE.

Simulation results revealed that the vigorous enforcement of well sealing (Scenario 1) would have a modest effect on land subsidence; however, the adverse impacts on the livelihood of the agricultural community were significant. Scenario 2, aimed at enhancing surface water utilization, improved land subsidence; however, the associated costs and adverse environmental impacts were notable. Scenario 3, aimed at reducing net consumptive use of water for irrigation, would provide substantial benefits in terms of land subsidence while maintaining the profitability of agricultural production. However, this mitigation policy requires government intervention to provide financial incentives for cultivation of less water-intensive crops and the adoption of advanced irrigation technology and automatic systems. Recently, the government has begun to encourage the agricultural sector to plant dry crops or less-water-intensive crops in severe land subsidence areas. Based on this plan, subsidies need to be granted by the central and local governments; this is absolutely not remarkable when compared to the calculated benefit from the switching to less-water-intensive crops. Even if subsidies are fully removed, the benefit will remain feasible due to the improvement in irrigation and farming technologies. Furthermore, agricultural extension services and nongovernmental organizations can play a significant role by training the farming communities to raise their awareness of water scarcity.

The current model considered the connections among water supply, water demand, and land subsidence. We did not consider the influence of land subsidence or various strategies on the environment, or the effects of reparation methods on economic performance. Including such factors in future models would make the proposed model more comprehensive. Note also that this study simulated only a single management strategy. In the future, researchers could evaluate a portfolio of strategies.

Author Contributions: Conceptualization, Y.-H.H., Y.-J.L. and J.-H.W.; methodology, Y.-H.H., Y.-J.L. and J.-H.W.; data curation, Y.-J.L.; writing-original draft preparation, Y.-H.H.; writing-review and editing, Y.-H.H. and J.-H.W.; supervision, J.-H.W.; funding acquisition, Y.-H.H. All authors have read and agreed to the published version of the manuscript.

Funding: This research was funded by the Ministry of Science and Technology, Taiwan, R.O.C. (grant number 109-2621-M-006-006-).

Institutional Review Board Statement: Not applicable.

Informed Consent Statement: Not applicable.

Data Availability Statement: All data are available in the public domain.

Conflicts of Interest: The authors declare no conflict of interest.

\section{Appendix A}

The equations in our SD model use either stocks or flows as variables. Stocks refer to accumulations used to characterize the state of a system in order to derive information upon which to base decisions. Flow is used to define rates capable of affecting a change in stocks. The accumulation of stocks is a function of the difference between inflow and outflow. A stock with one inflow and one outflow is formulated as follows:

$$
\operatorname{Stock}(t)=\operatorname{Stock}\left(t_{0}\right)+\int_{t_{0}}^{t}[\operatorname{Inflow}(t)-\text { Outflow }(t)] d t
$$

where Stock $(t)$ indicates the stock at time $t$, Stock $\left(t_{0}\right)$ indicates the stock at time $t_{0}$, Inflow $(t)$ indicates the inflow at time $t$, and Outflow $(t)$ indicates the outflow at time $t$. 
Land quantity is the main stock in the model. Annual changes in land quantity are controlled by land inflow (i.e., development) and land outflow (i.e., subsidence). The quantities of agricultural and industrial land at a time $t$ are respectively calculated as follows:

$$
\begin{gathered}
Q A L(t)=Q A L\left(t_{0}\right)+\int_{t_{0}}^{t}[A L D(t)-A L S(t)] d t \\
Q I L(t)=Q I L\left(t_{0}\right)+\int_{t_{0}}^{t}[I L D(t)-I L S(t)] d t
\end{gathered}
$$

where $Q A L(t)$ refers to the quantity of agricultural land at time $t, Q A L\left(t_{0}\right)$ indicates the quantity of agricultural land at time $t_{0}, A L D(t)$ indicates agricultural land development at time $t$, and $A L S(t)$ indicates agricultural land subsidence at time $t$. $Q I L(t)$ indicates the quantity of industrial land at time $t, Q I L\left(t_{0}\right)$ indicates the quantity of industrial land at time $t_{0}, I L D(t)$ indicates industrial land development at time $t$, and $I L S(t)$ indicates industrial land subsidence at time $t$.

The number of groundwater wells is another stock in our model. Inflow covers the excavation of groundwater wells, while outflow covers the sealing of groundwater wells. The number of groundwater wells at a time $t$ is calculated as follows:

$$
G W(t)=G W\left(t_{0}\right)+\int_{t_{0}}^{t}[E W(t)-S W(t)] d t
$$

where $G W(t)$ refers to number of groundwater wells at time $t, G W\left(t_{0}\right)$ indicates the number of groundwater wells at time $t_{0}, E W(t)$ indicates the number of excavated groundwater wells at time $t$, and $S W(t)$ indicates the number of sealed groundwater wells at time $t$.

The accumulated land subsidence level is derived from annual land subsidence using the following formula:

$$
A L S(t)=A L S\left(t_{0}\right)+\int_{t_{0}}^{t}[L S(t)] d t
$$

where $A L S(t)$ refers to the accumulated land subsidence level at time $t, A L S\left(t_{0}\right)$ indicates the accumulated land subsidence level at time $t_{0}$, and $L S(t)$ indicates the land subsidence level at time $t$.

\section{References}

1. Taylor, R.G.; Scanlon, B.; Doll, P.; Rodell, M.; van Beek, R.; Wada, Y.; Longuevergne, L.; Leblanc, M.; Famiglietti, J.S.; Edmunds, M.; et al. Ground water and climate change. Nat. Clim. Change 2013, 3, 322-329. [CrossRef]

2. Foster, S.; Chilton, J.; Nijsten, G.J.; Richts, A. Groundwater-A global focus on the 'local resource'. Curr. Opin. Environ. Sustain. 2013, 5, 685-695. [CrossRef]

3. Jeanne, P.; Farr, T.G.; Rutqvist, J.; Vasco, D.W. Role of agricultural activity on land subsidence in the San Joaquin Valley, California. J. Hydrol. 2019, 569, 462-469. [CrossRef]

4. Hwang, C.; Hung, W.C.; Liu, C.H. Results of geodetic and geotechnical monitoring of subsidence for Taiwan High Speed Rail operation. Nat. Hazards 2008, 47, 1-16. [CrossRef]

5. Qureshi, M.A. Human development, public expenditure and economic growth: A system dynamics approach. Int. J. Soc. Econ. 2009, 36, 93-104. [CrossRef]

6. Ghaffarzadegan, N.; Lyneis, J.; Richardson, G.P. How small system dynamics models can help the public policy process. Syst. Dyn. Rev. 2011, 27, 22-44. [CrossRef]

7. Von Loeper, W.; Musango, J.; Brent, A.; Drimie, S. Analysing challenges facing smallholder farmers and conservation agriculture in South Africa: A system dynamics approach. S. Afr. J. Econ. Manag. Sci. 2016, 19, 747-773. [CrossRef]

8. Wang, J.F.; Lu, H.P.; Peng, H. System dynamics model of urban transportation system and its application. J. Transp. Syst. Eng. Inf. Technol. 2008, 8, 83-89. [CrossRef]

9. Aparicio, S.; Urbano, D.; Gómez, D. The role of innovative entrepreneurship within Colombian business cycle scenarios: A system dynamics approach. Futures 2016, 81, 130-147. [CrossRef]

10. Nair, G.K.; Rodrigues, L.L.R. Dynamics of financial system: A system dynamics approach. Int. J. Econ. Financial Issues 2013, 3, 14-26.

11. Meadows, D.H.; Meadows, D.L.; Randers, J.; Behrens, W.W., III. The Limits to Growth: A Report for the Club of Rome's Project on the Predicament of Mankind; Universe Books: New York, NY, USA, 1972. 
12. Rong, L. Using System Dynamics in Decision Support for Sustainable Waste Management. Master's Thesis, Department of Civil Engineering, National University of Singapore, Singapore, 2004.

13. Simonovic, S.P. World water dynamics: Global modeling of water resources. J. Environ. Manag. 2002, 66, 249-267. [CrossRef]

14. Zhang, L.; Mitsch, W.J. Modelling hydrological processes in created freshwater wetlands: An integrated system approach. Environ. Model. Softw. 2005, 20, 935-946. [CrossRef]

15. Chen, C.H.; Liu, W.L.; Liaw, S.L.; Yu, C.H. Development of a dynamic strategy planning theory and system for sustainable river basin land use management. Sci. Total Environ. 2005, 346, 17-37. [CrossRef]

16. Khan, S.; Yufeng, L.; Ahmad, A. Analysing complex behaviour of hydrological systems through a system dynamics approach. Environ. Model. Softw. 2009, 24, 1363-1372. [CrossRef]

17. Wei, S.K.; Yang, H.; Song, J.X.; Abbaspour, K.C.; Xu, Z.X. System dynamics simulation model for assessing socio-economic impacts of different levels of environmental flow allocation in the Weihe river basin, China. Eur. J. Oper. Res. 2012, 221, 248-262. [CrossRef]

18. Xi, X.; Poh, K.L. Using system dynamics for sustainable water resources management in Singapore. Procedia Comput. Sci. 2013, 16, 157-166. [CrossRef]

19. Balali, H.; Viaggi, D. Applying a system dynamics approach for modeling groundwater dynamics to depletion under different economical and climate change scenarios. Water 2015, 7, 5258-5271. [CrossRef]

20. Alifujiang, Y.; Abuduwaili, J.; Ma, L.; Samat, A.; Groll, M. System dynamics modeling of water level variations of Lake Issyk-Kul, Kyrgyzstan. Water 2017, 9, 989. [CrossRef]

21. Ghasemi, A.; Saghafian, B.; Golian, S. System dynamics approach for simulating water resources of an urban water system with emphasis on sustainability of groundwater. Environ. Earth Sci. 2017, 76, 1-15. [CrossRef]

22. Mokhtar, A.; Aram, S. Systemic insights into agricultural groundwater management: Case of Firuzabad Plain, Iran. Water Policy 2017, 19, 867-885. [CrossRef]

23. Pluchinotta, I.; Pagano, A.; Giordano, R.; Tsoukiàs, A. A system dynamics model for supporting decision-makers in irrigation water management. J. Environ. Manag. 2018, 223, 815-824. [CrossRef]

24. Bai, Y.; Langarudi, S.P.; Fernald, A.G. System dynamics modeling for evaluating regional hydrologic and economic effects of irrigation efficiency policy. Hydrology 2021, 8, 61. [CrossRef]

25. Lo, C.Y. Study on the Managerial Strategy of Subsidence in Changha-Ynlin Area: Perspective of Collaborative Governance. Master's Thesis, Graduate Institute of National Policy and Public Affairs, National Chung Hsing University, Taichung, Taiwan, 2016. (In Chinese)

26. Liao, C.N.; Chen, B.H. Evaluation of the Effectiveness of a Subsidy Policy with Externality Consideration and the Flood Control Program in the Da-Cheng Township. Taiwan J. Appl. Econ. 2017, 101, 149-189. (In Chinese)

27. Glaser, B.; Strauss, A. The Discovery of Grounded Theory: Stretegies for Qualitative Research; Aldine: Chicago, IL, USA, 1967.

28. Forrester, J.W. Industrial Dynamics; Pegasus Communications: Waltham, MA, USA, 1961.

29. Ventana Systems. Vensim PLE 8.0; Ventana Systems, Inc.: Harvard, MA, USA, 2021. Available online: https://vensim.com/ vensim-software/ (accessed on 18 November 2021).

30. Yu, H.L.; Chu, H.J. Understanding space-time patterns of groundwater system by empirical orthogonal functions: A case study in the Choshui River alluvial fan, Taiwan. J. Hydrol. 2010, 381, 239-247. [CrossRef]

31. Chu, H.J.; Ali, M.Z.; Burbey, T. Development of a Groundwater-Drawdown Function to Estimate Spatially Varying Land Subsidence: A Case Study of the Choshui River Basin, Taiwan; Authorea Preprints: Tainan, Taiwan, 2020.

32. Yang, Y.S. Analysis and Modeling between Groundwater and Land Subsidence in Choushui River Alluvial Fan. Master's Thesis, Department of Resources Engineering, National Cheng Kung University, Tainan City, Taiwan, 2013. (In Chinese)

33. Executive Yuan. Concrete Solutions and Action Plans for Land Subsidence in Yunzhang Area; Executive Yuan: Taipei, Taiwan, 2011. (In Chinese) 